Original Article / Orijinal Araştırma

\title{
Kanserli Hastalarda Alkalen Fosfataz Düzeyi ile Kemik Sintigrafisinde Tespit Edilen Lezyon Sayısı Arasındaki İlişsinin Değerlendirilmesi
}

\section{The Patients with Cancer Evaluation the Relationship Between Alkaline Phosphatase Level and Number of Lesions Detected on Bone Scintigraphy}

\author{
Zekiye Hasbek $^{1}$, Serdar Savaş Gül ${ }^{2}$, Bülent Turgut ${ }^{1}$
}

${ }^{1}$ Cumhuriyet Üniversitesi Tip Fakültesi, Nükleer Tıp Anabilim Dalı, Sivas.

${ }^{2}$ Gaziosmanpaşa Üniversitesi Tıp Fakültesi, Nükleer Tıp Anabilim Dalı, Tokat.

\section{Corresponding Author:}

Dr. Zekiye Hasbek

\section{Address:}

Cumhuriyet Üniversitesi Tıp Fakültesi, Nükleer Tıp Anabilim Dalı, Sivas.

Tel: 05432712122

\section{E-mail:}

gopnukleertip@gmail.com

\section{Başvuru Tarihi/Received :}

07-04-2014

\section{Kabul Tarihi/Accepted:}

23-06-2014

\section{ÖZET}

Kemik metastazı genellikle kötü prognoz ile ilişkilidir. Kemik sintigrafisi ve serum alkalen fosfataz (ALP) düzeyi malignitelerde kemik metastazının deteksiyonu için kullanılır. Bu retrospektif çalışmadaki amacımız, kanser hastalarında kemik sintigrafisi ve serum ALP düzeyleri arasındaki ilişkiyi araştırmaktır.

Gereç-Yöntemler: Kemik sintigrafisi yaklaşık 20mCi Tc99m-MDP (Metilendifosfonat)'ın i.v. olarak verilmesiyle yapıldı. ALP seviyesi için referans aralı̆̆ı 35-105 IU/L idi. Hastalar sintigrafik bulgulara göre "metastatik lezyon yok", "tek kemik tutulumu", "2 kemik tutulumu" ve " 3 ve daha fazla kemik tutulumu" olarak 4 gruba ayrıldı.

Bulgular: 102 hastanın 53'ü meme kanseri, 16's1 akciğer kanseri, 16's1 prostat kanseri, 3'ü over kanseri, 2'si hasta testiskanseri, 2'si endometrium kanseri, 2'si pankreas kanseri, 2'si mide kanseri, 2'si tiroid kanseri, 2'si rektum kanseri, 1'i hasta özefagus kanseri ve 1'i mesane kanseri idi. Kemik metastazlı hastalarda ortalama serum ALP seviyesi kemik metastazı olmayanlardan yüksekti. Ortalama serum ALP seviyesi tek lezyonu olanlarda $92.76 \pm 26$ $\mathrm{IU} / \mathrm{L} ; 2$ lezyonu olan hastalarda $106.18 \pm 22 \mathrm{IU} / \mathrm{L} ; 3$ ve daha fazla lezyonu olan hastalarda $302.92 \pm 210 \mathrm{IU} / \mathrm{L}$ ve kemik metastazı olmayanlarda $70.07 \pm 17 \mathrm{IU} / \mathrm{L}$ idi.

Sonuç: Calışmamızda metastatik kemik lezyonu olmayanlarda ve tek metastaz izlenen hastalarda ALP seviyeleri normal değerler arasında, 2 lezyon bulunanlarda normalin üst seviyesinde iken; 3 lezyon ve üzerindekilerde anlamlı yükseklik mevcuttu. Sonuç olarak, iskelet sistemi metastazının değerlendirilmesi için kemik sintigrafisi yapılan hastalarda ALP düzeyine bakılmasının, kemik sintigrafisinin spesifitesini artıracağı düşünüldü.

Anahtar Kelimeler: Tüm Vücut Kemik Sintigrafisi, Alkalen Fosfataz

\section{ABSTRACT}

Bone metastasis is usually associated with poor prognosis. Bone scintigraphy (BS) and serum alkaline phosphatase level are used to detect bone metastasis in malignancy. This retrospective study aimed to examine the relationship among bone scintigraphy and serum ALP level in cancer patients.

Material-Methods: BS was performed by the i.v. administration of Tc99m-MDP (Methylendiphosphonate) at a dose of about $20 \mathrm{mCi}$. The reference range for ALP level was 35$105 \mathrm{IU} / \mathrm{L}$. Scintigraphic findings of the patients were divided into four groups regarding the number of lesion as; "no metastatic lesion", "one bone involvement", "two bones involvement" and "more than three-bones involvement".

Results: Fifty three of 102 patients had breast cancer; 16 patients had lung cancer; 16 patients had prostate cancer; 3 patients had ovary carcinoma, 2 patients had testicle cancer; 2 patients had endometrium cancer; 2 patients had pancreas cancer; 2 patients had gastric cancer; patients had thyroid cancer; 2 patients had rectum cancer; 1 patient had esophagus cancer and 1 patient had bladder cancer. The mean value of serum ALP level was higher in patients with bone metastasis than in patients without bone metastasis. The mean serum level of ALP was; $92.76 \pm 26 \mathrm{IU} / \mathrm{L}$ in patients with single bone involvement; $106.18 \pm 22 \mathrm{IU} / \mathrm{L}$ in patients with two bones involvement; $302.92 \pm 210 \mathrm{IU} / \mathrm{L}$ in patients with more than three-bones involvement and $70.07 \pm 17 \mathrm{IU} / \mathrm{L}$ in patients without bone metastasis.

Conclusion: In our study, while ALP levels were within normal values at patients without metastatic bone lesion and patients monitored with single metastasis, and these were above normal values at patients with 2 lesion; there was a significant increase at patients with 3 or more lesions. Consequently, it's been thought that controlling the ALP level of patients who had bone scintigraphy for evaluation of the skeletal system metastasis increase the specificity of the bone scintigraphy.

Key words: Whole Body Bone Scintigraphy, Alkaline Phosphatase 


\section{GíRiş}

Kemik metastazları birçok tümörde önemli bir prognoz faktörüdür. Prostat, meme, akciğer, tiroid ve renal kanserler en sık kemik metastazı yapan kanser türleridir (1). Metastatik olmayan kanserlerde tedavi edilebilme ihtimali yüksek iken, kemik metastazlarını tedavi etmek zordur. $\mathrm{Bu}$ nedenle erken tanı önemlidir. Akciğer kanserlerinde ilk tanı anında kemik metastazı olma oran1 \% 20-30'larda iken, bu oran meme kanserinde \% $1-2$ 'dir (2). Metastazlar direk yakın komşulukla yayılım gösterdiği gibi, hematojen veya lenfatik yolla da yayılım gösterebilir. Tümör hücrelerine karş1 oluşan cevaba göre litik, sklerotik ya da mikst tip metastazlar görülebilir. $\mathrm{Bu}$ farklılıklar tümörün etkisiyle osteoblastların (skleroz, periostal yeni kemik oluşumu), osteoklastların (destrüksiyon, lizis) veya her ikisinin birlikte aktivasyonu sonucunda gelişir.

Metastazların tanısının konulmasinda, direk grafi, kemik sintigrafisi (KS), 18F-FDG PET/BT (Flor18-FloroDeoksiGlukoz Pozitron Emisyon Tomografisi/Bilgisayarlı Tomografi), BT (Bilgisayarlı Tomografi) ve MR (Manyetik Rezonans) görüntüleme yöntemlerinin yanı sıra bazı serum biyobelirteçler de tanıda yardımcıdır. Kemik metastazının tanısı için bu tetkiklerden hangisinin tercih edileceği ile ilgili literatürde çok sayıda yayın olmakla birlikte, ideal görüntüleme tekniğinin hangisi olmas1 gerektiği hakkında bir fikir birliği yoktur. Bununla birlikte ortak kanı; kemik metastazlarının tespitinde, primer tümörün tipi dikkate alınarak yapabileceği kemik metastazının karakterinin bilinmesi, klinik ve laboratuvar bilgileri de dikkate alınarak farklı görüntüleme yöntemlerinin de kombinasyonu ile doğru tanı konulmasıdır (3).
$\mathrm{Bu}$ çalışmada değerlendirdiğimiz kemik sintigrafisi ve serum alkalen fosfataz (ALP), kemik metastazlarının tanısının konulmasında önemli yer tutar. Alkalen fosfataz (ALP) birçok doku tarafindan sentezlenmektedir. Karaciğer ve kemik orijinli alkalen fosfataz; serum alkalen fosfataz düzeyinin büyük kısmını oluştururlar. Kemik metastazlarında artan osteoblastik aktivite sonucu serum total ALP ve kemik ALP izoenziminde artış beklenmektedir (4). Biz retrospektif olan bu çalışmamızda, kemik sintigrafisindeki lezyon sayısı ile ALP düzeyleri arasındaki ilişkiyi araştırmayı planladık.

\section{YÖNTEM}

Çalışmaya histopatolojik olarak malignite tanısı almış ve iskelet sistemi metastazı değerlendirmesi amacıyla bölümümüze Tc-99m MDP (Metilendifosfonat) ile tüm vücut kemik sintigrafisi istemiyle gönderilen ve kemik sintigrafisi ile aynı haftada serum ALP düzeyleri bakılan hastalar dahil edildi. Kemik sintigrafi görüntüleri, yaklaşık $20 \mathrm{mCi}$ Tc-99m-MDP'nin (metilen difosfonat) i.v. enjeksiyonunun ardından 3-4 saat kadar sonra çift başlı bir gama kamerada (E-CAM 5500, Toshiba) tüm vücut tarama ve şüpheli bölgelerden statik görüntüler alınarak elde edildi. Kemik sintigrafisi iki nükleer tıp uzmanı tarafından, hastaların kayıtlı tüm klinik, laboratuvar ve diğer görüntüleme bulguları da incelenerek değerlendirildi. Kemik sintigrafisi bulgularına göre hastalar "metastatik lezyon yok", "tek lezyon tutulumu", "2 lezyon tutulumu" ve " 3 ve daha fazla lezyon tutulumu" olarak 4 gruba ayrıldı. Serum ALP düzeyi için referans aralığ 1 35-105 IU/L idi (Tablo 1).

İstatistik analiz için SPSS 15.0 otomatik istatistik programı kullanıldı. Metastatik lezyon yokluğu ve lezyon sayıları ile ortalama serum ALP seviyeleri arasındaki karşılaştırmada ANOVA testi kullanıldı. Karşılaştırmalarda $\mathrm{p}<0.05$ değeri anlamlı olarak kabul edildi. 
Tablo 1. Hastalara ait demografik ve klinikopatolojik veriler.

\begin{tabular}{|c|c|}
\hline Özellikler & $\mathrm{n}(\%)$ \\
\hline \multicolumn{2}{|l|}{ Yas } \\
\hline Tanı anında ortalama yaș (yil) & $57\left(27-81 \mathrm{y}_{1}\right)$ \\
\hline \multicolumn{2}{|l|}{ Cinsivet } \\
\hline Kadin & $66(\% 528)$ \\
\hline Erkek & $36(\% 28,8)$ \\
\hline \multicolumn{2}{|l|}{ Histopatoloiik Siniflama } \\
\hline Meme $\mathrm{Ca}$ & $53(\% 51.96)$ \\
\hline Akciğer $\mathrm{Ca}$ & $16(\% 15.68)$ \\
\hline Prostat $\mathrm{Ca}$ & $16(\% 15.68)$ \\
\hline Oyer Ca & $3(\% 2.94)$ \\
\hline Testis $\mathrm{Ca}$ & $2(\% 1.96)$ \\
\hline Endometrium $\mathrm{Ca}$ & $2(\% 1.96)$ \\
\hline Pankreas $\mathrm{Ca}$ & $2(\% 1.96)$ \\
\hline Mide $\mathrm{Ca}$ & $2(\% 1.96)$ \\
\hline Tiroid $\mathrm{Ca}$ & $2(\% 1.96)$ \\
\hline Rektum $\mathrm{Ca}$ & $2(\% 0.98)$ \\
\hline Özefagus Ca & $1(\% 0.99)$ \\
\hline Mesane $\mathrm{Ca}$ & $1(\% 0.99)$ \\
\hline
\end{tabular}

\section{BULGULAR}

Çalışmaya, yaşları 27-81 olan (ortalama $57 \pm 11$ yaş) ve kemik sintigrafisinde, kemik metastazı olmayan 53 hasta ile, metastatik kemik lezyonu izlenen 49 hasta olmak üzere toplam 102 hasta dahil edildi. Hastalara ait demografik ve klinikopatolojik veriler Tablo 1 'de sunulmuştur. Hastalardan 66's1 kadın (\%52.8), 36's1 erkekti (\%28.8). Elli üç hasta meme ca (\%51.96), 16 hasta akciğer ca (\% 51.68), 16 hasta prostat ca (\% 51.68), 3 hasta over ca (\% 2.94), 2 hasta testis ca (\% 1.96), 2 hasta endometrium ca (\% 1.96), 2 hasta pankreas ca (\% 1.96), 2 hasta mide ca (\% 1.96), 2 hasta tiroid ca (\% 1.96), 2 hasta rektum ca (\% 1.96),
1 hasta özefagus ca (\% 1.96) ve 1 hastada mesane ca (\% 1.96) idi. Kemik sintigrafisinde osteoblastik lezyon izlenmeyen hastalarda ortalama serum ALP düzeyi $70.07 \pm 17 \mathrm{IU} / \mathrm{L}$ iken; tek lezyonu olanlarda 92.76 $\pm 26 \mathrm{IU} / \mathrm{L} ; 2$ lezyonu olanlarda $106.18 \pm 22 \mathrm{IU} / \mathrm{L} ; 3$ ve daha fazla lezyonu olanlarda $302.92 \pm 210 \mathrm{IU} / \mathrm{L}$ olarak bulundu (Tablo 2). ANOVA testi ve ardindan yapılan Post Hoc Multiple Comparison ile Tukey testi tablosu incelendiğinde, üç ve ve daha fazla lezyonu olanlarda diğer tüm gruplarla karşılaştırıldığında anlamlı farklılık görüldü $(\mathrm{p}=0.0001)$. Ancak diğer lezyon sayıları dikkate alındığında gruplar arasında anlamlı farklılık yoktu $(\mathrm{p}>0.05)$.

Tablo 2. Kemik sintigrafi bulguları serum ALP düzeyleri arasındaki ilişki $(\mathrm{p}<0.05)$

\begin{tabular}{|l|l|}
\hline Lezyon Sayısı & Serum ALP düzeyleri (IU/L) \\
\hline Lezyon yok & $70.07 \pm 17$ \\
\hline Tek lezyon & $92.76 \pm 26$ \\
\hline 2 lezyon & $106.18 \pm 22$ \\
\hline 3 ve daha fazla lezyon & $302.92 \pm 210$ \\
\hline
\end{tabular}


DOI: $10.16899 /$ ctd.90093

\section{TARTIŞMA}

Onkolojik hastalarda kemik metastazları, özellikle şiddetli kemik ağrıları, hiperkalsemi, patolojik kırıklar ve spinal kord basısı nedeniyle, morbiditeyi artıran en önemli sebeplerdendir ve tedavi planının belirlenmesinde oldukça önemlidir. Metastazların erken tespiti komplikasyonların önlenmesi ve dolayısıyla yaşam kalitesinin iyileşmesi açısından önemlidir. Kemik metastazlarında kemik rezorbsiyonu osteoklastlar, tümör hücreleri, makrofajlar veya monositler aracılığ 1 ile gelişebilir. Osteoblastların stimülasyonu da osteoklast fonksiyonlarını artırabilmektedir (1). Klinik olarak bifosfonatlar, kemik rezorbsiyonunu önler ve kemiğin büyüme faktörlerinin salınımını azaltır. Kemik metastazları herhangi bir kemikte ve lokasyonda görülebilmesine rağmen, omurgada ve pelviste apendiküler kemiklere göre çok daha sık görülür.

Serum ALP düzeyi, klinik pratikte sıklıkla kullanılır ve kemik turnoverinin biyokimyasal belirtecidir. Sağlıklı bireylerde ALP aktivitesinin yarısı kemikten, diğer yarısı da karaciğerden köken alır. Kemik metabolizması biyobelirteçlerinin, kemik metastazı sırasında gelişen kemik formasyonu ve rezorbsiyonunu yansıttığı düşünülmektedir (5). Her ne kadar kemik metastazlarının tanı ve takibinde yeni biyokimyasal belirteçler araştırılmaya devam ediyor olsa da, serum ALP birçok tümörde kemik metastazlarının tespitinde s1klıkla kullanılan ancak spesifitesi düşük olan bir biyokimyasal testtir (6-9). Spesifitesinin düşük olmasının sebepleri arasında, yalnızca kemikten köken almıyor olmasının yanısıra, sigara içimi, kan şekerindeki artış, kilo artışı gibi durumlardan da etkilenmesi yer almaktadır (6). $\mathrm{Bu}$ enzim asıl olarak osteoblastların plazma membranında bulunur ve osteoid formasyonunda ve mineralizasyonunda önemli rol oynar (10). Biz çalışmamızda metastazı olmayan hastalarda serum ALP seviyesi normal limitler içinde yer alıyorken, metastazı olanlarda yüksek olarak bulundu.
Tc99m-MDP ile yapılan kemik sintigrafisi, yüksek duyarlılığa sahip olması, tüm iskelet sistemini kolay ve hızlı değerlendirme olanağ1 sağlaması ve diğer görüntüleme tetkiklerine göre ucuz olması nedeniyle kemik metastazlarının değerlendirilmesinde sıklıkla kullanılmaktadır (11). Asemptomatik hastalarda bile doğru evreleme/yeniden evreleme için rutin olarak kemik sintigrafisinin kullanılması önerilmektedir (12). Çünkü Tc99m MDP'nin kemiklerde tutulumu, kemik turnover belirteçleri ile ilişkilidir (14). Ancak ALP seviyesi normal olan asemptomatik hastalarda, kemik sintigrafisinin yapılmaması yönünde görüşler de mevcuttur (13). Multiple myelomda olduğu gibi litik lezyonlarda da kemik sintigrafisi ile değerlendirme yapmak güçtür. Ayrıca boyutu $<1 \mathrm{~cm}$ olan medüller lezyonlar ile korteksi tutmayan lezyonlarda metastazı tespit oranı düşüktür (15). Osteoblastik kemik metastazlarının saptanmasında ise kemik sintigrafisi, spesifitesi kısmen düşük olmakla birlikte en duyarlı görüntüleme yöntemidir (9). Hatta yanlış negatiflik oranı çoğu tümörde ancak \% 2 kadardır (11). Kemik sintigrafisi, kemik metastazlarını henüz anatomik değişiklikler oluşmadan önce (direkt grafi bulguların ortaya çıkmasından en az 3 ay önce) saptayabilir. Ancak kanserli olduğu bilinen ya da şüphelenilen bir hastada kemik sintigrafisinde saptanan tek bir lezyonun metastaz olma olasılığını belirleme zordur. Kemik sintigrafisinde tek malign lezyonu tespit oranı \%50-55 oranındadır (16). Eğer primer tümör başarı ile tedavi edildiyse tek metastazlar küratif uygulamalar ile tedavi edilebilir. Min ve arkadaşları (17) yalnızca kemik sintigrafisi yapılanlardaki spesifitenin ( $\%$ 44.1), kemik sintigrafisi ile birlikte ALP seviyesinin de değerlendirildiği hastalardaki spesifiteye göre (\% 97.3) düşük olduğunu rapor etmişlerdir. Ayrıca nodal ve kemik dışı organ açısından değerlendirme yapılmasına gerek olmayan hastalarda, kemik sintigrafisi ve serum ALP seviyesinin asemptomatik kemik lezyonlarının gösterilmesinde yeterli olacağını rapor etmişlerdir. 


\section{DOI: $10.16899 /$ ctd. 90093}

Bizim çalışmamızda metastatik kemik lezyonu olmayanlarda ve tek lezyon izlenen hastalarda ALP seviyeleri normal değerler arasinda, 2 lezyon bulunanlarda normalin üst seviyesinde iken; 3 lezyon ve üzerindekilerde anlamlı yükseklik mevcuttu. Sonuç olarak, iskelet sistemi metastazının değerlendirilmesi için kemik sintigrafisi yapılan hastalarda ALP düzeyine bakılmasının, kemik sintigrafisinin spesifitesini artıracağ 1 düşünülmektedir.

\section{KAYNAKLAR}

1. Tyrrell PNM, Cassar-Pullicino VN, Lalam RK, Tins BJ. Bone Metastases 1: Spine. Chapter 26. In: Davies AM, Sundaram M, James SLJ (eds). Imaging of Bone Tumors and Tumor-Like Lesions. Springer-Verlag Berlin Heidelberg 2009:461-79.

2. Damle NA, Bal C, Bandopadhyaya GP, Kumar L, Kumar P, Malhotra A, Lata S. The role of 18F-fluoride PET-CT in the detection of bone metastases in patients with breast, lung and prostate carcinoma: a comparison with FDG PET/CT and 99mTcMDP bone scan. Jpn J Radiol. 2013;31(4):262-9.

3. Choi YJ, Shin YD, Kang YH, Lee MS, Lee MK, Cho BS, Kang YJ, Park JS. The Effects of Preoperative (18)F-FDG $\mathrm{PET} / \mathrm{CT}$ in Breast Cancer Patients in Comparison to the Conventional Imaging Study. J Breast Cancer. 2012;15(4):441-8.

4. Ortapamuk H, Arslan A, Naldöken S, Doğrar A, Genç H, Esen M. Kemik Metastazlarının Saptanmasında Alkalen Fosfataz Kemik İzoenziminin Değeri ve Kemik Sintigrafisi İle Karşılaştırılması. T Klin Tıp Bilimleri 2001, 21:180-185.

5. Meijer WG, van der Veer E, Willemse PH. Biochemical parameters of bone metabolism in bone metastases of solid tumors (review). Oncol Rep. 1998;5(1):5-21.

6. Rajarubendra N, Bolton D, Lawrentschuk N. Diagnosis of Bone Metastases in Urological Malignancies-An Update. Urology. 2010;76(4):782-90.

7. Bayrak SB, Ceylan E, Serter M, Karadağ F, Demir E, Çildağ $\mathrm{O}$. The clinical importance of bone metabolic markers in detecting bone metastasis of lung cancer. Int $\mathrm{J}$ Clin Oncol. 2012;17(2):112-8

8. Leeming DJ, Koizumi M, Byrjalsen I, Li B, Qvist P, Tankó LB. The relative use of eight collagenous and noncollagenous markers for diagnosis of skeletal metastases in breast, prostate, or lung cancer patients. Cancer Epidemiol Biomarkers Prev. 2006;15(1):32-8.

9. Ebert W, Muley T, Herb KP, Schmidt-Gayk H. Comparison of bone scintigraphy with bone markers in the diagnosis of bone metastasis in lung carcinoma patients. Anticancer Res. 2004;24(5B):3193-201

10. Wakabayashi H, Nakajima K, Mizokami A, Namiki M, Inaki A, Taki J, Kinuya S. Bone scintigraphy as a new imaging biomarker: the relationship between bone scan index and bone metabolic markers in prostate cancer patients with bone metastases. Ann Nucl Med. 2013;27(9):802-7.

11. Metler FA, Guiberteau MJ. Essentials of Nuclear Medicine Imaging. Chapter 8. Skeletal System. 6th ed. Elsevier Inc 2012;271-314.

12. Erturan S, Yaman M, Aydin G, Uzel I, Müsellim B, Kaynak K. The role of whole-body bone scanning and clinical factors in detecting bone metastases in patients with non-small cell lung cancer. Chest. 2005;127(2):449-54.

13. Schindler F, Lajolo PP, Pinczowski H, Fonseca FL, Barbieri A, Massonetto LH, Katto FT, Del Giglio A. Bone and total alkaline phosphatase for screening skeletal metastasis in patients with solid tumours. Eur J Cancer Care (Engl). 2008;17(2):152-6.

14. Lenora J, Norrgren K, Thorsson O, Wollmer P, Obrant $\mathrm{KJ}$, Ivaska KK. Bone turnover markers are correlated with total skeletal uptake of $99 \mathrm{mTc}-$ methylene diphosphonate $(99 \mathrm{mTc}-$ MDP). BMC Med Phys. 2009;30;9:3.

15. Taoka T, Mayr NA, Lee HJ, Yuh WT, Simonson TM, Rezai K, Berbaum KS. Factors influencing visualization of vertebral metastases on MR imaging versus bone scintigraphy. AJR Am J Roentgenol. 2001;176(6):1525-30.

16. Ahn JB, Ha TK, Kwon SJ. Bone metastasis in gastric cancer patients. J Gastric Cancer. 2011;11(1):38-45.

17. Min JW, Um SW, Yim JJ, Yoo CG, Han SK, Shim YS, Kim YW. The role of whole-body FDG PET/CT, Tc 99m MDP bone scintigraphy, and serum alkaline phosphatase in detecting bone metastasis in patients with newly diagnosed lung cancer. J Korean Med Sci. 2009;24(2):275-80. 